\title{
Terrapene coahuila Schmidt and Owens 1944 - Coahuilan Box Turtle
}

\author{
Jennifer G. Howeth ${ }^{1,3}$ ANd William S. Brown ${ }^{2,4}$ \\ ${ }^{1}$ Section of Integrative Biology, University of Texas at Austin, Austin, Texas 78712 USA; \\ ${ }^{2}$ Department of Biology, Skidmore College, Saratoga Springs, New York 12866 USA; \\ ${ }^{3}$ Present Address: Department of Biological Sciences, University of Alabama, \\ Tuscaloosa, Alabama 35487 USA [jghoweth@as.ua.edu]; \\ ${ }^{4}$ Present Address: Department of Biological Sciences, State University of New York at Albany, \\ Albany, New York 12222 USA [wbrown@skidmore.edu]
}

Summary. - The Coahuilan Box Turtle, Terrapene coahuila (Family Emydidae), endemic to the Cuatro Ciénegas Basin of central Coahuila, Mexico, is internationally recognized as endangered due to its naturally restricted geographic range and substantial loss of habitat in the past half-century. The only extant aquatic member of the genus, $T$. coahuila is a small species (carapace length to 230 $\mathrm{mm}$ ) that occupies shallow wetland habitats distributed across the Cuatro Ciénegas valley floor. Water diversion from man-made canals within the basin, and groundwater exploitation in contributing aquifers outside of the basin, have lowered the valley's water table and resulted in widespread wetland habitat desiccation, thus jeopardizing the species' viability. The most extensive aquatic habitat loss has occurred in the western portion of the basin, west and northwest of Sierra de San Marcos y Pinos, where a genetically distinct subpopulation of $T$. coahuila resides. Habitat loss threatens the persistence of $T$. coahuila, and if not curtailed, will lead to the extinction of the species in the wild in Cuatro Ciénegas. Proposed conservation measures include: 1) upgrading the species' conservation status with the Mexican government from a Species of Special Protection to Endangered, 2) formulating an integrative species management plan with the Mexican government that includes local and regional regulation and monitoring of water extraction to ensure persistence of critical wetland habitats, 3) long-term monitoring of key populations, including estimation of population size and density, 4) identification and preservation of critical dispersal corridors associated with long-distance movements of migratory populations, and 5) measures to reduce road mortality.

Distribution. - Mexico. Restricted to the Cuatro Ciénegas Basin, Coahuila.

Synonymy. - Terrapene coahuila Schmidt and Owens 1944, Terrapene ornata coahuila.

SubSPECIES. - None.

Status. - IUCN 2011 Red List: Endangered (EN A2c+4c; B1ab (i, ii, iii, iv, v) + 2b (i, ii, iii, iv, v)) (assessed 2007); CITES: Appendix I; US ESA: Endangered; Mexico: Species of Special Protection.

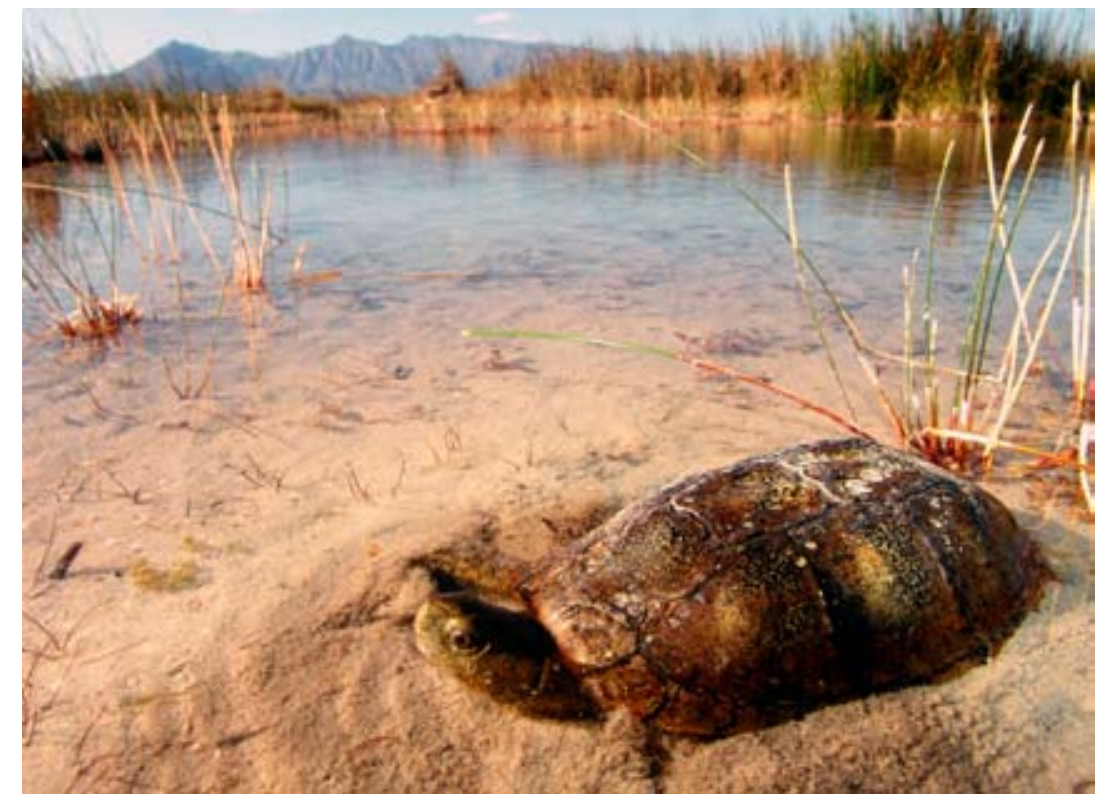

Figure 1. Terrapene coahuila in Cuatro Ciénegas, Mexico. Photo by Jason M. Jones, www.herpfotos.com. 


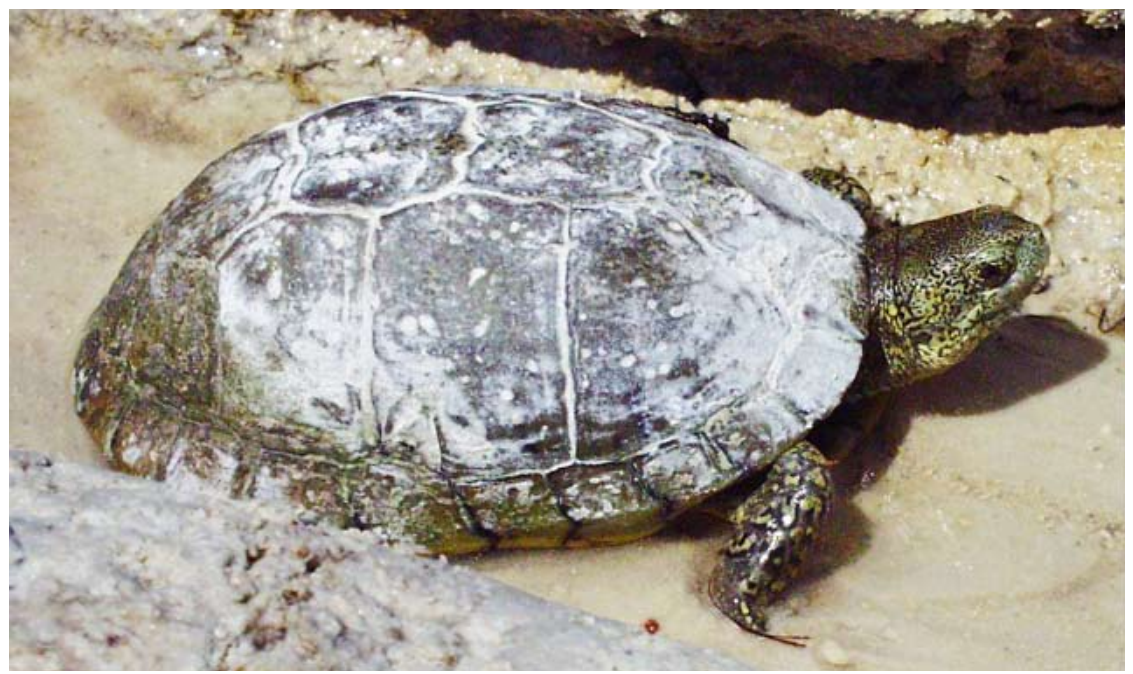

Figure 2. Terrapene coahuila in Cuatro Ciénegas, Mexico. Photo by Jennifer G. Howeth.

Taxonomy. - The Coahuilan Box Turtle, Terrapene coahuila, was originally described by Schmidt and Owens (1944) as a species endemic to the $840 \mathrm{~km}^{2}$ intermontane basin of Cuatro Ciénegas in central Coahuila, Mexico. Terrapene coahuila has historically been considered a full species with the exception of an early unsubstantiated proposition by Mertens and Wermuth (1955) that the taxon be considered a subspecies of $T$. ornata. There are no recognized subspecies of T. coahuila.

Phylogenetic relationships within extant Terrapene, and the position of $T$. coahuila in particular, remain unresolved (reviewed in Smith and Smith 1979; Stephens and Wiens 2003). Studies based upon morphological (Milstead 1960; Milstead 1967; Milstead and Tinkle 1967; Minx 1996), molecular (Feldman and Parham 2002), and combined morphological and molecular data (Stephens and Wiens 2008) suggest that $T$. coahuila is the sister species to $T$. carolina. Other studies (Bramble 1974; Burke et al. 1996), however, suggest that T. coahuila or T. carolina mexicana (Stephens and Wiens 2003) is sister to a group containing

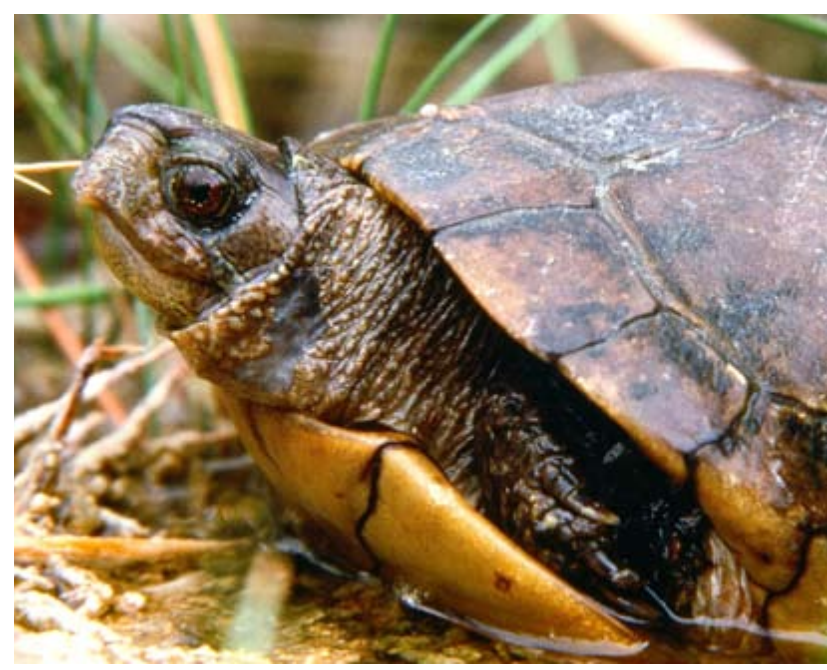

Figure 3. Terrapene coahuila in Cuatro Ciénegas, Mexico. Photo by Ramon Mascort. the remaining three extant species of the genus. A recent review of the literature by Iverson et al. (2007, from the 2005 Turtle Genetics Workshop) indicates that the most robust phylogenies support T. coahuila as the sister taxon to T. carolina. Some of the discrepancy among contemporary phylogenies of the emydids may stem from the selection of genes utilized in the analysis (e.g., mtDNA vs. nucDNA; Wiens et al. 2010).

Description. - A number of morphological and behavioral traits distinguish $T$. coahuila from its three extant
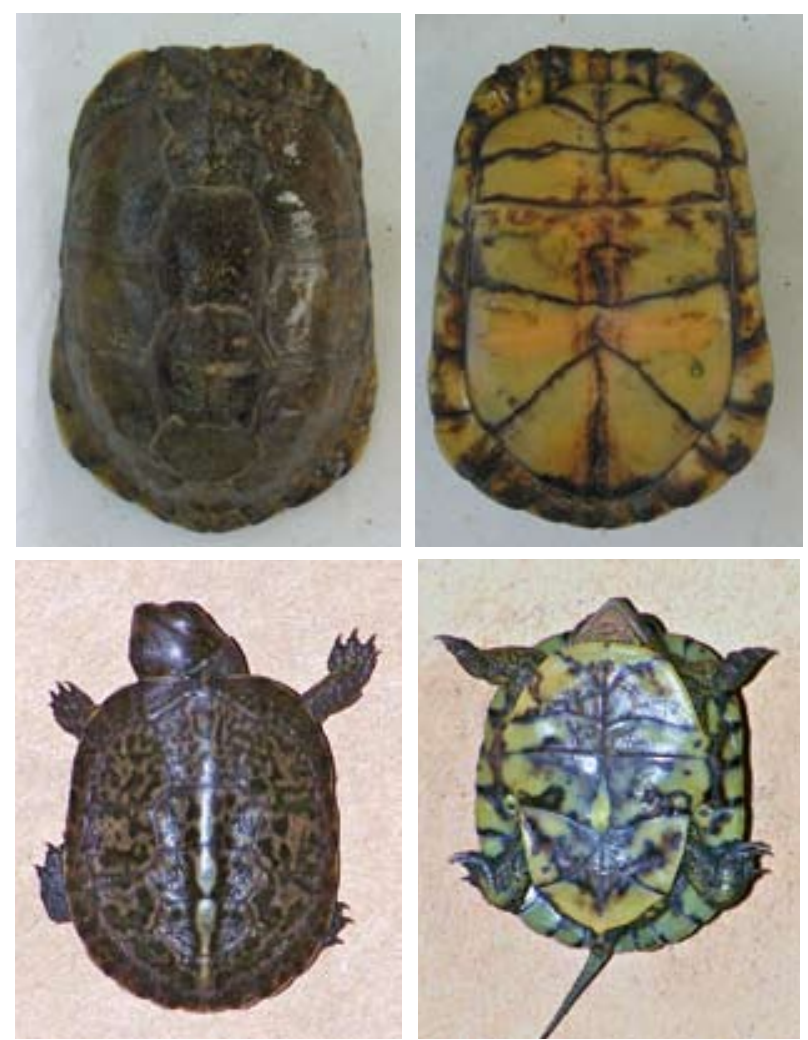

Figure 4.Terrapene coahuila. Top: Adult male fromLaguna Grande, Cuatro Ciénegas, Mexico. Photo by Jennifer G. Howeth. Bottom: Hatchling (2 days old) at the Gladys Porter Zoo, Brownsville, Texas. Photos by Patty Scanlan. 

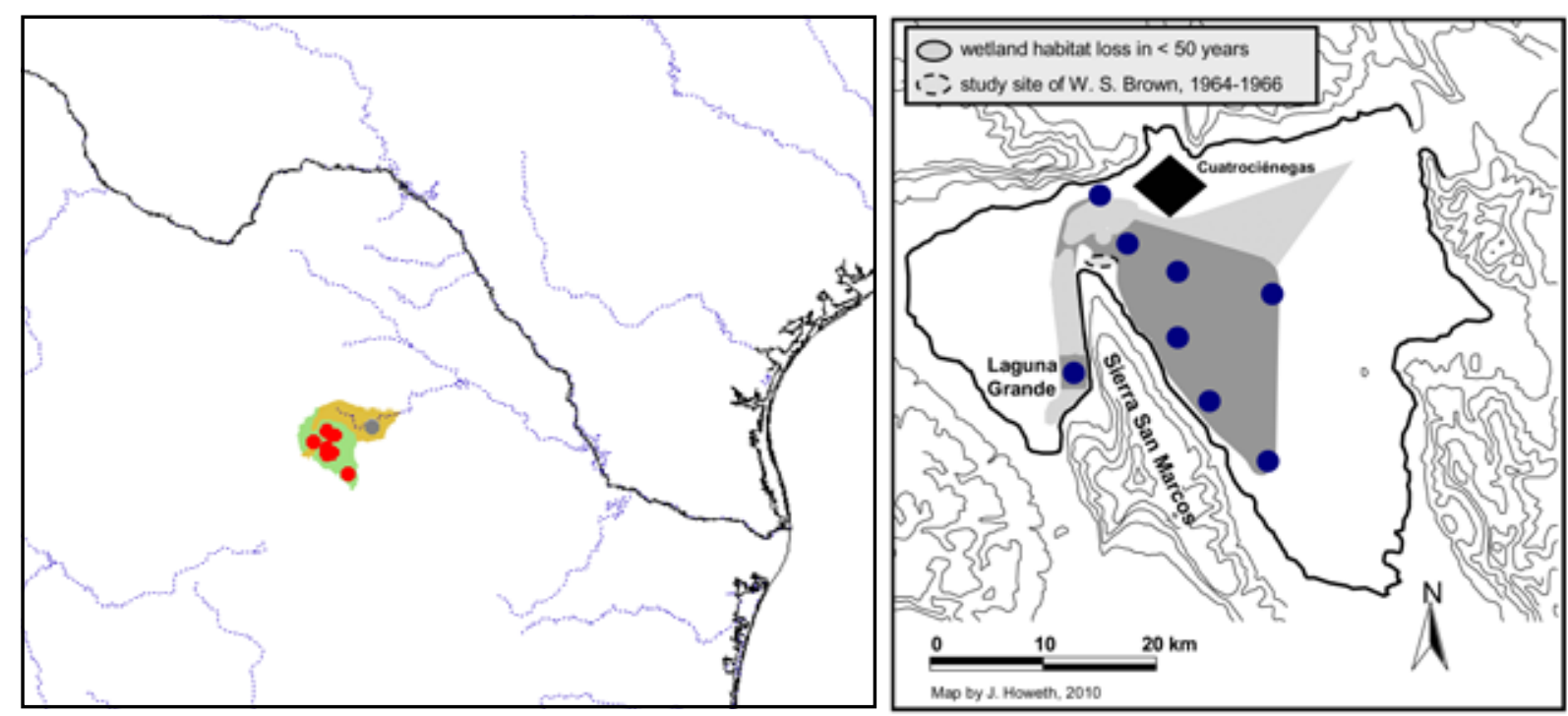

Figure 5. Left: Distribution of Terrapene coahuila in Coahuila, Mexico. Red dots $=$ museum and literature occurrence records of native populations based on Iverson (1992) plus more recent and authors' data; gray dot = extirpated population; olive shading = extirpated range; green shading = projected distribution based on GIS-defined hydrologic unit compartments (HUCs) constructed around verified localities and then adding HUCs that connect known point localities in the same watershed or physiographic region, and similar habitats and elevations as verified HUCs (Buhlmann et al. 2009), and adjusted based on authors' data. Right: The Cuatro Ciénegas Basin (bold outline) and the current geographic range of T. coahuila (grey polygon). Distribution is denoted by known sites of collection or sight records, 2002-07 (solid circles), and has been greatly reduced compared to the historic distribution, 1958-68 (Fig. 2 in Brown 1974). See Fig. 6 for photographic illustration of habitat loss from 1965-2002. Documented T. coahuila wetland habitat loss has primarily occurred in the western and northern sections of the geographic range. The town of Cuatrociénegas de Carranza (diamond) is the human population center of the valley and supports irrigated agriculture.

congeners, T. carolina, T. nelsoni, and T. ornata. Notably, T. coahuila is the only aquatic species of the genus. Phylogenetic uncertainty has implications for the evolutionary origin of the aquatic adaptations of $T$. coahuila, as the three other species of Terrapene are terrestrial. Aquatic traits in $T$. coahuila may be recently derived in response to the spring-fed wetlands of Cuatro Ciénegas (Milstead 1960; Brown 1971; Feldman and Parham 2002) or may be basal in the genus (Auffenberg 1958; Bramble 1974; Legler 1960; Williams et al. 1960). The body density of $T$. coahuila is higher than that of T. carolina, thereby potentially facilitating submergence in aquatic environments relative to more buoyant terrestrial species (Williams and Han 1964). Cloacal bursae are an additional distinguishing character of $T$. coahuila relative to other extant congeners and these respiratory structures are suggested as primitive (basal) in Terrapene (Williams et al. 1960). The carapace and skin coloration of $T$. coahuila are typically a uniform dark olive-brown (Figs. 1-3). Terrapene coahuila lacks the characteristic yellow-orange carapace speckling and stripes of its congeners, but often (ca.71\% of samples, Brown 1971) has pale golden-yellow vermiculations highlighting a dark brown carapace (Fig. 3; Schmidt and Owens 1944). The plastron of adults is a uniform dull yellow with irregular brown markings at the scute margins. The carapace and plastron of hatchlings is similar in coloration to adults, but with enhanced dichromatic patterning (Fig. 4).

Pronounced sexual dimorphism occurs in T. coahuila. Brown (1971) outlined four external traits which best differentiate sex in the species: 1) adult males have a plastral concavity which is absent in females, 2) adult males have a thicker tail at the base and a longer tail relative to females, 3) males have a brown iris flecked with yellow, whereas females display a reverse color pattern of the iris, and 4) the ratio of shell depth to carapace length in males averages $43 \%$ and in females $46 \%$. Males have more greatly flared marginals (Brown 1971) and a more prominently notched maxillary beak (Schmidt and Owens 1944; Webb et al. 1963) as compared to females. Sexual size dimorphism also occurs in T. coahuila: Brown (1971) reported a mean straight-line carapace length of $108.9 \mathrm{~mm}$ (range $81.9-143.5 \mathrm{~mm} ; \mathrm{n}=$ 70) for males and $100.9 \mathrm{~mm}$ (range 88.5-114.1 mm; $\mathrm{n}=94$ ) for females from a single population located at the base of the northern tip of Sierra de San Marcos y Pinos (hereafter, Sierra de San Marcos). A survey of multiple populations in 2002 reinforced Brown's (1971) findings of sexual size dimorphism, where adult males are significantly larger than adult females (straight-line carapace length, mean \pm $\mathrm{SD}$, range: males $=144.4 \pm 23.4 \mathrm{~mm}, 97.0-230.0 \mathrm{~mm}, \mathrm{n}$ $=314$; females $=127.7 \pm 11.3 \mathrm{~mm}, 99.1-199.3 \mathrm{~mm}, \mathrm{n}=$ 338; Howeth, unpubl. data). Interestingly, the overall body size of both sexes in this survey was much greater than that found by Brown (1971). These comparative body size data suggest considerable geographic variation in age structure or individual growth rates.

Distribution. - Terrapene coahuila is endemic to the Cuatro Ciénegas Basin in central Coahuila, Mexico (Fig. $5)$. The geographic range of $T$. coahuila is constrained by the mountains of the Sierra Madre Oriental that surround the closed $840 \mathrm{~km}^{2}$ basin. The Cuatro Ciénegas valley is characterized by Chihuahuan Desert biota and spring-fed pools or pozas and numerous shallow wetlands or cienegas 
(Minckley and Cole 1968). Terrapene coahuila inhabits both permanent and seasonal wetlands that are distributed across the valley floor. Over the last century, extensive loss of wetland habitat due to surface and groundwater diversion via man-made canals and wells has fragmented once continuous wetlands into spatially discrete wetland complexes separated by large extents of terrestrial matrix
(Hendrickson et al. 2008). As a consequence, populations of $T$. coahuila are currently distributed discontinuously across the basin.

The most comprehensive record of the historic geographic distribution of $T$. coahuila is based on a map provided by W. L. Minckley and reported in Brown (1974). In a recent survey conducted by Howeth (2002, unpubl.
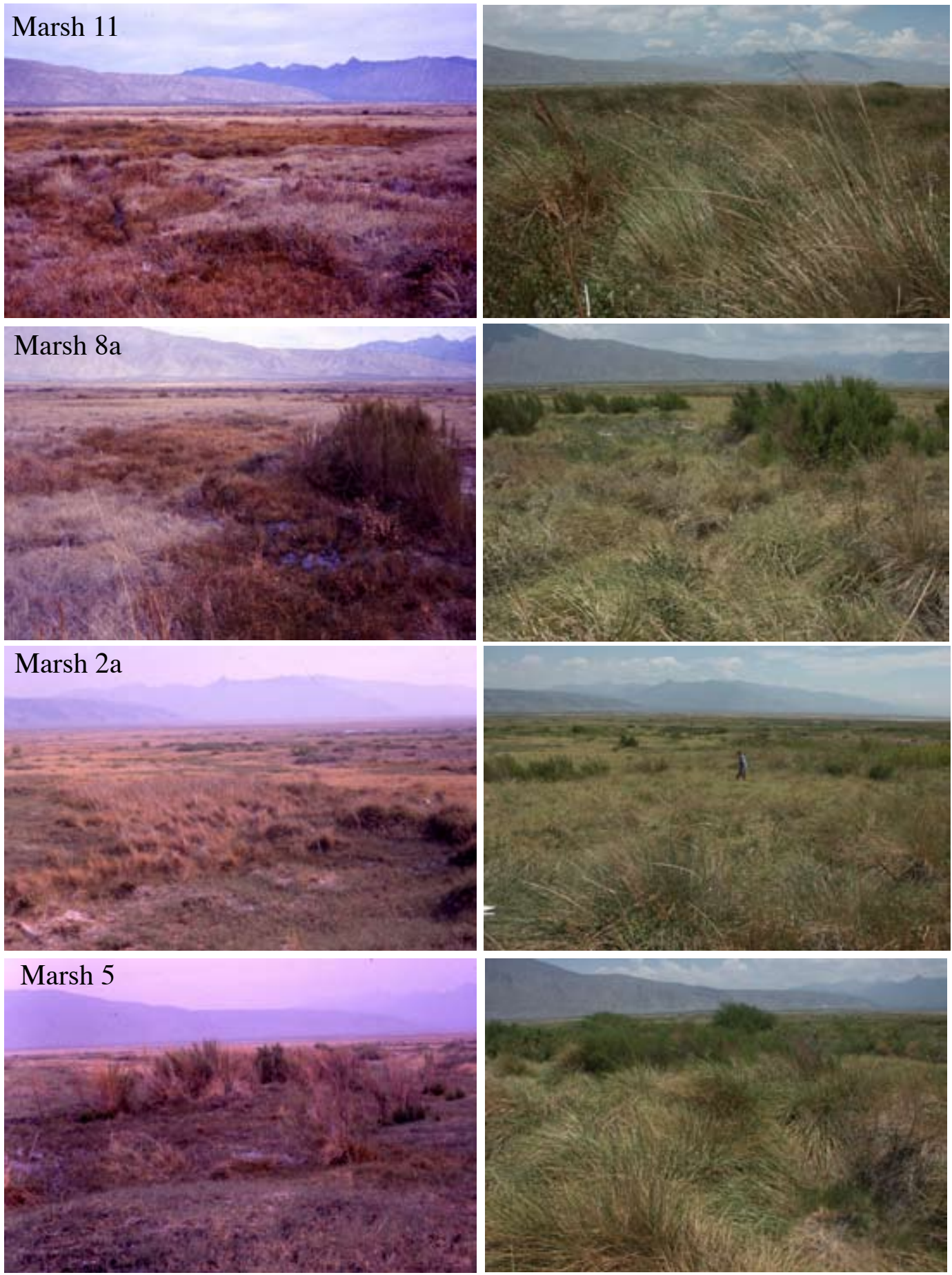

Figure 6. Terrapene coahuila wetland habitat loss over a 37-year period (1965-2002) in Cuatro Ciénegas, Mexico. Photos show the study sites of W.S. Brown located north of the tip of Sierra de San Marcos (see Fig. 5). See Brown (1974) for detailed descriptions of individual wetlands. Top to bottom paired photographs, 1965 on left, 2002 on right: Marsh 11 on 22 December 1965 and 6 July 2002 ; Marsh 8a on 22 December 1965 and 6 July 2002; Marsh 2a on 14 April 1965 and 6 July 2002; and Marsh 5 on 14 April 1965 and 6 July 2002. Photos from 1965 by William S. Brown and from 2002 by a resurvey team including W.S. Brown, J.G. Howeth, Dean A. Hendrickson, and Arturo Contreras-Arquieta. 
data) of these historic distribution sites and other sites of occurrence obtained through local reports, the geographic range of $T$. coahuila was found to be contracted, primarily collapsing from the northeast and the west towards the core of the range (Fig. 5). Most of the abandoned habitats were desiccated while others were degraded by livestock. Specifically, historic study sites of Brown (1967, 1974) located at the eastern base of the northern flank of Sierra de San Marcos (2654'54.94”N, 10207’37.98”W) are now permanently dry and in the late stages of succession (Figs. 5-6). A large laguna located northwest of Las Salinas $\left(26^{\circ} 56^{\prime} 46.35^{\prime} \mathrm{N}, 102^{\circ} 05^{\prime} 45.37^{\prime \prime} \mathrm{W}\right)$ which previously supported box turtle habitat is now completely dry (Arturo Contreras-Arquieta, pers. comm., 2002). Other desiccated historic habitats include extensive wetlands west of Sierra de San Marcos, located immediately west of Poza de La Becerra (2652'40.83'N, 10208'21.43'W), fed by the now-dessicated Río Garabatal (2654'21.63”N, $102^{\circ} 09^{\prime} 43.78^{\prime \prime} \mathrm{W}$; Fig. 5). Photographic illustration of habitat loss at both of these sites over a 40-year period is documented by Hendrickson et al. (2008). Two additional wetland habitats, which served as the southwestern range boundary, located at and just north of Ejido San Marcos ('San Marcos' in Fig. 3 of Webb et al. 1963) are degraded and/or eutrophied via livestock to the point of apparent unsuitability for $T$. coahuila $\left(26^{\circ} 48^{\prime} 37.31^{\prime \prime} \mathrm{N}\right.$, $102^{\circ} 09^{\prime} 02.19^{\prime \prime} \mathrm{W} ; 26^{\circ} 49^{\prime} 57.20^{\prime \prime} \mathrm{N}, 102^{\circ} 08^{\prime} 34.32 \mathrm{~W}$; Arturo
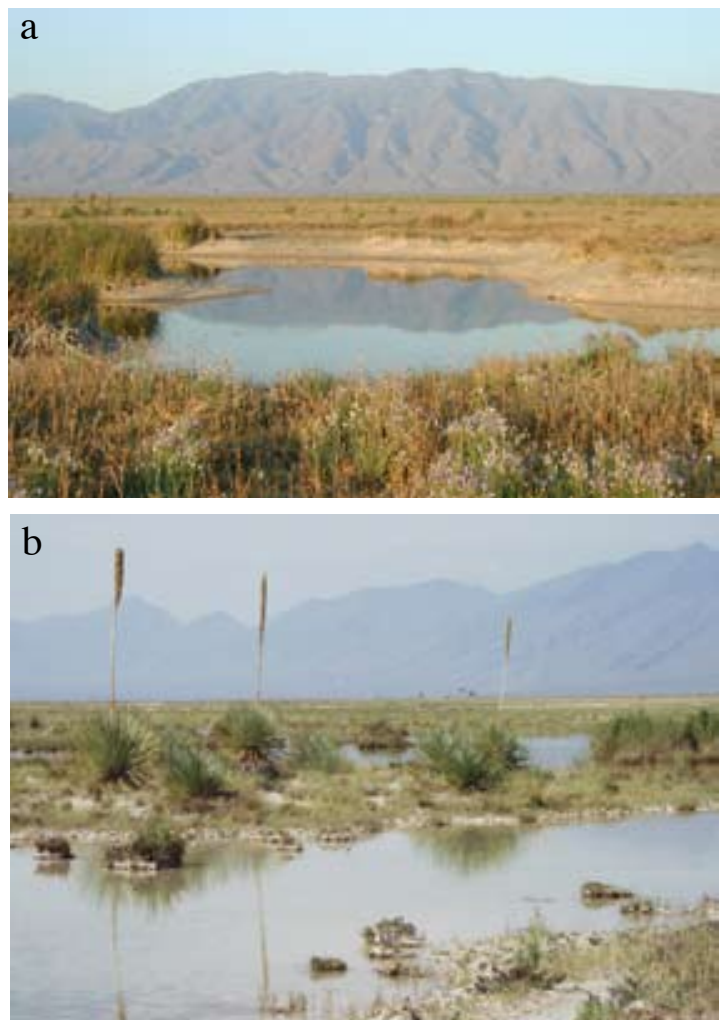

Contreras-Arquieta, pers. comm., 2002).As a consequence, it appears that the Río Churince drainage (including Laguna Grande), located $1 \mathrm{~km}$ north of Ejido San Marcos, presently serves as the southwestern range boundary of $T$. coahuila (Fig. 5). Wetlands which defined the northwest range boundary near Poza Anteojo, as described in Webb et al. (1963), have been excavated and dried by a locally extensive canal system. Finally, in the northeastern portion of the basin along the Saca Salada Canal, as indicated by the map in Brown (1974), no wetlands were found. Taken together, these findings suggest that the geographic range of $T$. coahuila is at most $360 \mathrm{~km}^{2}$ (van Dijk et al. 2007), but the current range appears to have further decreased in size since this 2007 estimate (see Population Status section below).

Habitat and Ecology. - Terrapene coahuila populations are located in shallow wetland habitats distributed throughout the Cuatro Ciénegas valley (Fig. 7; Webb et al. 1963; Brown 1974; Howeth et al. 2008). Rivers, lagunas, and pozas appear to be transitional habitats used during dispersal events. Wetlands occupied by T. coahuila represent the full range of hydrodynamics (ephemeral to permanent) and conductivity $(1,394$ to $11,020 \mu \mathrm{S})$ generally characterizing the wetlands of Cuatro Ciénegas (Fig. 7 ). The complete wetland gradient was encompassed by sites surveyed in Howeth et al. (2008), and the associated site-specific abiotic parameters are reported in Hendrickson
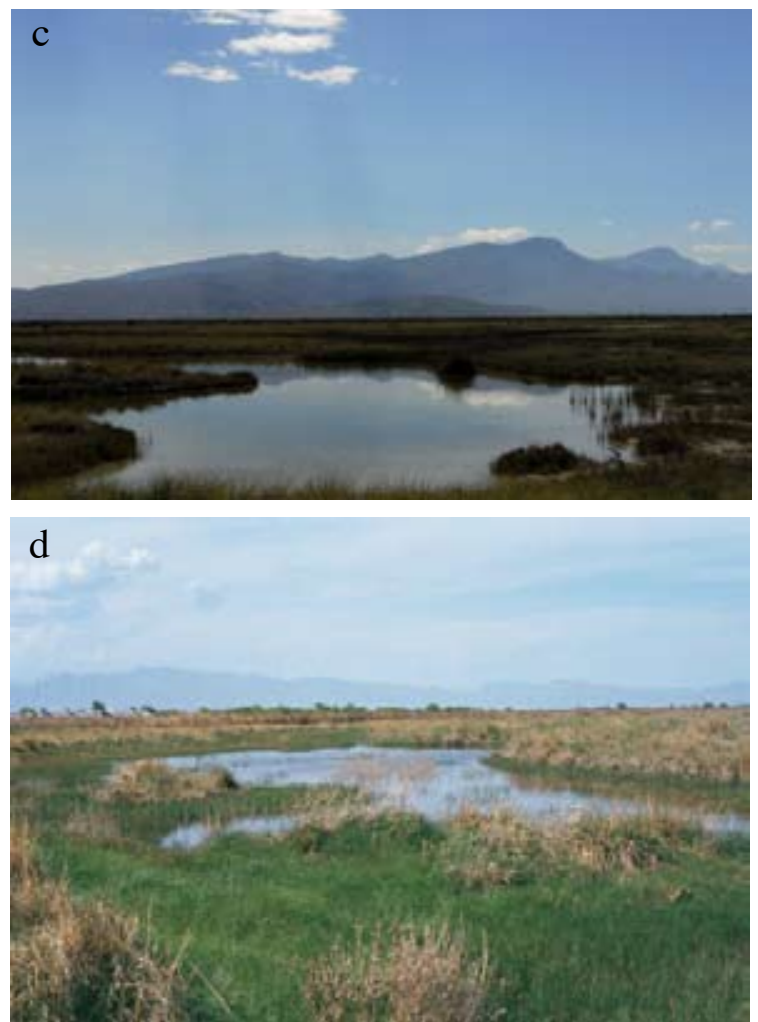

Figure 7. Terrapene coahuila habitat in Cuatro Ciénegas, Mexico. These wetlands represent the two extreme wetland habitat types in the Cuatro Ciénegas Basin. (a) Permanent wetland with Sierra de San Marcos in the background. Photo by J. Howeth; (b) Permanent wetland with Sierra de San Marcos in the background. Photo by J. Howeth; (c) Permanent wetland with Sierra de La Purísima in the background. Photo by Marsha Miller, 9 August 2008; (d) Seasonal wetland at Antiguos Mineros. Photo by J. Howeth, April 2002. Wetlands (a), (b), and (c) are highest in total dissolved solids (high conductivity), wetland (d) is lowest in total dissolved solids (low conductivity; Hendrickson et al. 2008). 

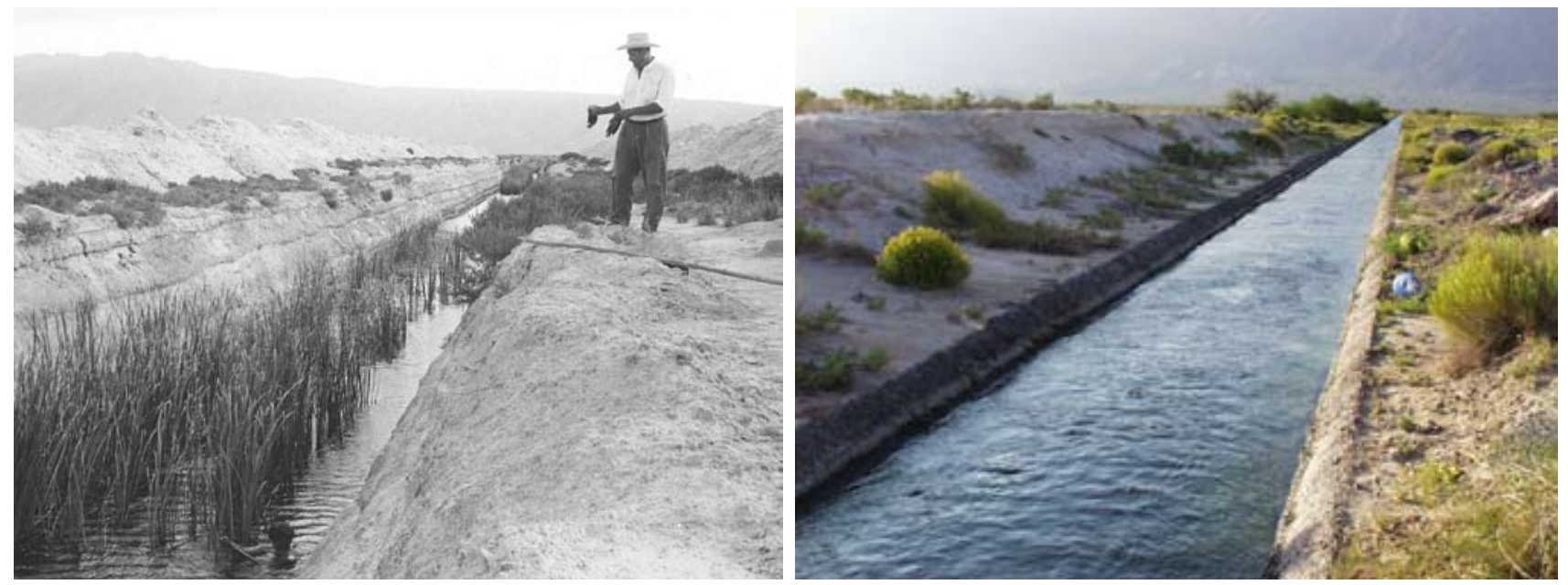

Figure 8. Man-made canals in Cuatro Ciénegas divert water to agricultural crops within and outside of the basin. The water extraction and diversion is largely responsible for rapid Terrapene coahuila wetland habitat loss over the last half-century. Left: Saca Salada Canal, 1965 (for location, see 'New Canal' in Fig. 3 of Webb et al. 1963), with Sierra de San Marcos in the background. Photo by William S. Brown, 28 August 1965. Right: Canal de La Becerra, 1998, with Sierra de La Madera in the background. Photo by Dean A. Hendrickson, 2 July 1998.

et al. (2008). Dominant vegetation in occupied wetlands includes Carex spp., Chara sp., Cladium mariscus, Distichlis stricta, Eleocharis rostellata, Fimbrystilis thermalis, Schoenoplectus americanus, and Scirpus olneyi (Brown 1974; Pinkava 1984).

Population Structure. - Coahuilan Box Turtles can be locally abundant within individual wetlands and wetland complexes. Brown (1974) estimated a population density of 148 individuals per hectare (95\% CI: 122-189/ ha) from mark-recapture. Based upon this estimate, associated $T$. coahuila biomass $(32.3 \mathrm{~kg} / \mathrm{ha})$ is higher than a reported average for semi-aquatic turtle species (19.2 $\mathrm{kg} / \mathrm{ha}$; Iverson 1982). Approximately 40 years after the study by Brown (1974), a different region of the species' range was investigated by Howeth et al. (2008). Using the number of individuals caught per daily capture effort (not an estimated population size) for each wetland surveyed, the population density of $T$. coahuila was lower than this earlier estimate, but absolute densities varied greatly by the wetland sampled. Howeth et al. (2008) found that $T$. coahuila density ranged from 0.60 to $66.67 \mathrm{ind} / \mathrm{ha} /$ capture effort (where capture effort is wetland/survey day). Of the 37 wetlands surveyed (range: $0.06-18.36 \mathrm{ha}$ ), the larger wetland habitats supported significantly higher turtle densities than did the smaller wetlands.

Basic demographic information for $T$. coahuila in Cuatro Ciénegas, including survival and longevity rates, are unknown. Of the 164 individuals marked by Brown (1974), a single individual was fortuitously recaptured in 1980 by Bruce Bury (pers. comm.). This turtle, an adult female, was marked in 1965 measuring $103.0 \mathrm{~mm} \mathrm{CL}$, and 15 years later was measured at $104.9 \mathrm{~mm} \mathrm{CL}$, an increase of $1.9 \mathrm{~mm}$. Reproductive potential was estimated by Brown (1974) from field-captured individuals. Approximately $75 \%$ of both males and females were sexually mature, based upon the value of the lower $95 \%$ confidence interval for threshold size at sexual maturity $(97.3 \mathrm{~mm}$ CL in females, $104.6 \mathrm{~mm}$
$\mathrm{CL}$ in males). Assuming a rough estimate for attainment of adult size based upon estimates in T. carolina (Stickel and Bunck 1989), an age of sexual maturity is postulated at 15 years. Likewise, the lifespan of T. coahuila is estimated to be over 65 years (Miller 2001).

There is significant variation in body size (carapace length) across the small geographic range of $T$. coahuila (Howeth, unpubl. data). Spatial variation in body size, and probably age structure, may be consequences of site-specific differences in resource availability, thereby affecting growth rates. Although sexual size dimorphism in the species is evident, the geographic differences in size structure cannot be attributed to spatially or temporally skewed sex ratios. In seven populations which exhibited geographic variation in size, sex-ratios did not significantly differ from 1:1 (Howeth, unpubl. data). Additionally, Brown (1974) found that sex ratios did not differ from 1:1 within a single population surveyed over multiple mark-recapture efforts spanning a two-year period.

An analysis of fine-scale genetic structure in seven populations located across the species' range suggests moderate levels of gene flow in $T$. coahuila, with an average $F_{\mathrm{ST}}$ of 0.01 (based upon nine microsatellite markers; Howeth et al. 2008). From this analysis, a significant relationship of genetic isolation by geographic distance across the species' range provides evidence for regional dispersal limitation. The isolation-by-distance relationship was driven exclusively by one population located at Laguna Grande (Río Churince drainage), the only population sampled west of Sierra de San Marcos (Fig. 5). The Laguna Grande population contained the highest genetic diversity of the seven populations sampled and thus we view its conservation as critical to the maintenance of overall genetic variation in $T$. coahuila. Interestingly, endemic fishes (Cyprinodon spp.) and an endemic spring snail (Mexipyrgus churinceanus) also exhibit distinct genetic structure in populations located west of Sierra de San Marcos (Carson and Dowling 2006; 
Johnson 2005). These congruent geographic patterns among diverse endemic aquatic taxa indicate a shared evolutionary history for populations west of Sierra de San Marcos and further underscore the biological importance of the $T$. coahuila population located at Laguna Grande.

Diet. - Terrapene coahuila is omnivorous and opportunistic, feeding on approximately equal proportions of aquatic plants and insects. In a study examining stomach contents of 45 wild-caught individuals, Brown (1974) found that insects (50.7\%) and plant material (45.6\%) were the most prominent components of the diet. Plant material was present in $84.4 \%$ of the stomachs and consisted largely of Eleocharis rostellata (64.4\% of plant material), with mushroom remains (15.6\%) and Chara spp. (11.1\%) occurring less frequently. Stratiomyid flies (Diptera) were the most common insects in the diet, with larvae occurring in $64.4 \%$ of the stomachs. Crustaceans, spiders, and fishes were also observed in the stomachs, but only at low frequencies (ca. 1\%). Comparisons of stomach contents between individuals captured in spring (April) to those captured in late summer (July, August) suggest seasonal variation in diet composition, although additional research is needed to understand temporal patterns of diet composition relative to food availability in the wetland habitat. According to Brown (1974), the T. coahuila population examined for diet more closely resembled aquatic species of other turtle genera in its food habitats than it did the terrestrial species of Terrapene.

Reproduction. - Size at sexual maturity for Terrapene coahuila males in Cuatro Ciénegas is approximated to be between 104.6 and $114.4 \mathrm{~mm}$ carapace length (CL) based on the presence of the sperm in the epididymides in a sample of 14 males (Brown 1974). For a sample of 30 females, size at sexual maturity is estimated to be between 97.3 and $105.9 \mathrm{~mm}$ CL based upon the presence of at least one ovarian follicle $>5 \mathrm{~mm}$ in diameter (Brown 1974). Female $T$. coahuila thus mature at a significantly smaller size than males. According to both the number and size of follicles present in the reproductive females examined by Brown (1974), ovulation likely occurs during the first week in April with oviposition beginning in May. Ovulation apparently continues into August and oviposition into early September, with multiple clutches possible throughout the summer. Terrapene coahuila females have the potential to lay approximately 3 clutches per year, with clutch sizes averaging 2.7, 2.4, and $1.7 \mathrm{eggs}$ in the first, second, and third clutch, respectively (Brown, 1974). Based upon data from pre-ovulatory follicular counts, females with a CL of 90-100 mm can lay 2 eggs per clutch; females $100-110$ $\mathrm{mm}, 3$ eggs; and females $>110 \mathrm{~mm}, 4$ eggs. Brown (1974) further determined clutch size in 16 female $T$. coahuila from the presence of oviductal eggs, corpora lutea, and enlarged ovarian follicles. From this analysis, he estimated an overall mean clutch size of 2.3 eggs (range 1-4) in T. coahuila. Eggs from oviducts of preserved females had the following dimensions: ( \pm 1 SE, $n=9$ eggs), length $33.2 \pm 0.67 \mathrm{~mm}$ (range $30.5-36.3 \mathrm{~mm}$ ) and width $16.9 \pm 0.28 \mathrm{~mm}$ (range
$15.8-18.2 \mathrm{~mm}$ ). The eggs weighed $5.66 \pm 0.30 \mathrm{~g}$ (range $4.44-6.81 \mathrm{~g}$ ). Additional details of $T$. coahuila reproduction, including age at sexual maturity, nest site choice, and temperature thresholds for temperature-dependent sex determination, have been evaluated in captivity.

Reproduction in Captivity. - Much of the current knowledge of reproduction beyond the initial work of Brown (1974) comes from captive breeding programs. Terrapene coahuila reproduces with relative ease in captivity (Baur and Jasser-Häger 2006). Successful reproduction has been documented in both outdoor enclosures (e.g., Dallas Zoo, Texas, USA) and indoor facilities (e.g., Jersey Wildlife Preservation Trust, currently Durrell Wildlife Conservation Trust, Jersey Zoo, Jersey) year-round (Murphy and Mitchell 1984; Cerda and Waugh 1992; Bauer and JasserHäger 2006). Pre-mating behavior observed in captivity includes the male biting at the female's head and impeding her movement (Murphy and Mitchell 1984). Copulation in captive T. coahuila primarily occurs in the shallow water of their artificial habitats (Murphy and Mitchell 1984; Cerda and Waugh 1992) and lasts for an average duration of 61 minutes (Cerda and Waugh 1992). The seasonal timing of oviposition varies depending upon the colony, with apparent peaks during the summer. Females typically lay clutches late in the evening in loose, slightly moist substrate (e.g., gravel, sand) near vegetation (Cerda and Waugh 1992; Bauer and Jasser-Häger 2006). At the Jersey Trust, there were $4.3 \pm 1.57$ eggs per clutch (mean $\pm \mathrm{SD} ; \mathrm{n}=36$ clutches), with $2.4 \pm 1.9$ fertile eggs and $1.2 \pm 1.7$ infertile eggs (Cerda and Waugh 1992). The eggs measured $30.4 \pm$ $3.25 \mathrm{~mm}$ in length, $19.4 \pm 3.13 \mathrm{~mm}$ in width, and weighed $6.43 \pm 1.21 \mathrm{~g}$ (mean $\pm \mathrm{SD} ; \mathrm{n}=88 \mathrm{eggs})$. Egg shells were cream-colored or white, brittle, and easily deformed under pressure. The mean incubation period per egg was 46.3 days in an incubator. Temperature during incubation determines sex of $T$. coahuila hatchlings (i.e. temperature-dependent sex determination, TSD), where a temperature of $28^{\circ} \mathrm{C}$ throughout incubation produces females and temperatures of $26-27^{\circ} \mathrm{C}$ produce males (Bauer and Jasser-Häger 2006). At the Jersey Trust, newly hatched T. coahuila weighed 4.4 g on average (Cerda and Waugh 1992) but private breeders report an average hatchling mass of 10-12 $\mathrm{g}$ (Bauer and Jasser-Häger 2006).

Growth in Captivity. - The detailed husbandry records of the Jersey Trust impart the most comprehensive growth and development data yet published for T. coahuila. The six founding $T$. coahuila ( 3 males, 3 females) of the Trust's colony were full siblings obtained from the Dallas Zoo in 1982, and were progeny of wild-caught individuals (Matthias Goetz, Durrell Wildlife Conservation Trust, pers. comm.). These six individuals were weighed monthly from the time of acquisition at 6 months of age to maturity. From the age of 6 to 52 months, females grew at a significantly faster rate than males (Cerda and Waugh 1992). Males, however, grew for 7 months longer prior to reaching maturity. The growth rates of the offspring of these founding individuals were tracked for four years. The offspring had 
the highest growth rates during their first year of life, with very high proportional increases in total body mass. At 4 yrs of age, sex in these turtles was still unknown. According to German breeders, however, sex in T. coahuila can be reliably determined at a minimum mass of $100 \mathrm{~g}$, which corresponds to 3 yrs of age for individuals in their colonies (Bauer and Jasser-Häger 2006). They report that captive females are approximately $100 \mathrm{~mm}$ in CL and 4 yrs old when sexually mature.

Predation. - Vertebrate predation likely impacts populations of T. coahuila in Cuatro Ciénegas. Minckley (1966) observed coyote (Canis latrans) predation on both T. coahuila and Trachemys taylori at Laguna Grande. There is also evidence for coyote predation in multiple populations from tooth marks on the carapace, and missing or partial limbs, in subadult and adult T. coahuila (Brown 1974; Howeth, unpubl. data). Additionally, nest predation by raccoons (Procyon lotor) may be a threat to T. coahuila. Raccoon tracks have been observed in wetlands occupied by turtles, including those near the Ejido Antiguos Mineros (Howeth, pers. obs.).

Activity and Movements. - Terrapene coahuila is considered semi-aquatic to aquatic (Webb et al. 1963). The swimming speed of $T$. coahuila $(1.55 \mathrm{CL} / \mathrm{second}, \mathrm{n}=2)$, standardized by carapace length, is comparable to that of other semi-aquatic emydids (e.g., Emydoidea blandingii, Glyptemys insculpta, G. muhlenbergii), but lower than the speed of fully aquatic emydids (e.g., Graptemys nigrinoda, G.ouachitensis, G.versa,Trachemys scripta), as determined by Stephens and Wiens (2008) in laboratory trials. From the same study, aquatic endurance, measured as the percentage of the maximum speed observed after 20 min of continuous locomotion, was $100 \%$ in T. coahuila - the highest relative value of the 16 emydids tested, with the exception of one other fully aquatic species (Deirochelys reticularia). In contrast, the terrestrial speed of $T$. coahuila $(1.11 \mathrm{CL} / \mathrm{s}, \mathrm{n}=$ 2) was found to be lower than that of T. carolina $(1.68 \mathrm{CL} / \mathrm{s}$, $\mathrm{n}=3)$ and $T$. ornata $(1.75 \mathrm{CL} / \mathrm{s}, \mathrm{n}=3$; Stephens and Wiens 2008).

In Cuatro Ciénegas, it appears that $T$. coahuila spends more time in terrestrial habitats than the two other cooccurring, fully aquatic turtles, Apalone spinifera atra and Trachemys taylori (Howeth, pers. obs.). Coahuilan Box Turtles exhibit crepuscular behavior, being most active in the mornings and evenings (Webb et al. 1963; Brown 1974). Periods of activity, however, are dependent upon ambient air and water temperature and are thus seasonally dependent. Turtles are generally most visible and active from 0700 to 1100 hours from May to October and from 1100 to 1400 hours from November to April (Howeth et al. 2008).

Howeth et al. (2008) found that T. coahuila exhibits two classes of movement behavior: frequent short movements among local wetlands within a wetland complex, and relatively infrequent long-distance (regional) dispersal between wetland complexes. In a mark-recapture study from 1964-66 focusing on a single small wetland complex (ca. $0.5 \mathrm{~km}^{2}$ ), approximately $50 \%$ of recaptured turtles were located in a wetland different from that in which they were originally marked (Brown 1974). There was no significant difference in mean straight-line movements between wetlands by sex, with an average distance of 84.6 $\mathrm{m}$ (maximum, $250 \mathrm{~m}$ ) for males and $62.1 \mathrm{~m}$ (maximum, 140 m) for females. From these data, Brown (1974) estimated an average home range radius of $12.8 \mathrm{~m}$. A more recent mark-recapture study examined inter-wetland movements over a two-month period in 2002, and within a different and much larger (ca. $2 \mathrm{~km}^{2}$ ) wetland complex than that surveyed by Brown (1974). Here, Howeth et al. (2008) found only $10 \%$ of recaptured turtles located in a wetland different from the one where they were marked originally. Despite the relatively lower inter-wetland movement rate, turtles traveled greater distances between wetland habitats, with a mean straight-line distance of $280 \mathrm{~m}(\mathrm{n}=17$ dispersal events) and a maximum of $513 \mathrm{~m}$. Wetland size (total area), rather than inter-wetland distance, appeared more important in determining movement patterns (Howeth et al. 2008). Collectively, these results suggest that $T$. coahuila frequently traverses short distances between wetlands. This movement behavior may be in response to heterogeneous resource availability among local wetland habitats.

In addition to local movements within wetland complexes, T.coahuila infrequently disperses remarkably long distances between wetland complexes. These long-distance dispersal events can be initiated by weather (e.g., rain; Webb et al. 1963) or by wetland habitat hydroperiod (e.g., drying), and occur less frequently than local-scale movements (Howeth et al. 2008). While long-distance dispersal events are less frequent, they may be relatively more important genetically than local-scale movements. For example, in a mark-recapture study involving intensive sampling of two populations monthly for one year (2002-03), highly asymmetric inter-population dispersal was detected (Howeth et al.2008). The long-distance movement events corresponded to a straight-line distance of $9.71 \mathrm{~km}$. A high emigration rate observed in one population (Antiguos Mineros) was a response to the complete drying of seasonal wetlands that occurred in May and persisted through November of the same year. Mark-recapture data for subsequent years showed that patterns of long-distance movements were predictable annually in response to wetland desiccation, at least at Antiguos Mineros (Howeth, unpub. data). Long-distance movements between the two populations appeared to be facilitated by an abandoned, unlined canal (the old Santa Tecla Canal) that retained water and wetland vegetation year-round and effectively served as a dispersal corridor (Fig. 8). An analysis of gene flow between the two populations showed high, asymmetric migration that reflected the same directional patterns. These findings indicate that $T$. coahuila dispersal and population genetic structure may be strongly shaped by the hydroperiod of seasonal wetlands in Cuatro Ciénegas.

Population Status. - Terrapene coahuila is considered here to be in danger of extinction from rapid wetland habitat 
loss. As wetland habitats continue to decline, populations will be further impacted. In the western portion of the valley, from the Río Churince drainage to Poza Anteojo, populations are critically low in density (Howeth, unpubl. data). The low densities in these areas are likely a consequence of the substantial amount of wetland habitat loss in the region, including the loss of the once extensive wetlands around Poza de la Becerra and Poza Anteojo. At the study sites of Brown (1974) in 2002, we documented a complete and drastic conversion of the once viable small marshes to dry and unsuitable grass-choked remnants over a 37-year period (Fig.6). The marshes and the turtles have disappeared. Johnson (2005) and Hendrickson et al. (2008) have also documented habitat loss and conversion in the basin.

There are indications that additional complete desiccation of many currently viable turtle habitats may be imminent. For example, Laguna Grande, a shallow lake fed by Río Churince and one of the largest lagunas in the basin (> 30 ha), was completely dry in 2006. According to local residents, this was the first time Laguna Grande had dried, encompassing at least 50 years conservatively (Dean Hendrickson, pers. comm.). Further, in December 2007 the seasonal wetlands at Antiguos Mineros did not refill as they historically do during the winter. In 2009, substantial drops in head-spring discharge rates at key $T$. coahuila habitats located range-wide suggest a grim outlook for wetland habitat viability in the immediate future (Instituto Nacional de Ecología 2009).

A drop in the water table may diminish recruitment in $T$. coahuila by decreasing available wetland habitat. Recently, low numbers of hatchlings have been encountered in the field (only 2 hatchlings from 2002-07; Howeth, unpubl. data and Suzanne McGaugh, pers. comm.), as compared to an expectation of higher numbers suggested by counts of adult females. Recruitment limitation is likely associated with the loss of aquatic habitat, decline in habitat quality, and increased drying (change in hydroperiod) of seasonal wetlands. Of the seven populations surveyed in Howeth et al. (2008), the largest appears to be located along the northeastern range boundary where aquatic habitats are relatively more stable. However, in the past five years the associated wetlands in this area have experienced large-scale desiccation (Dean Hendrickson, pers. comm., Instituto Nacional de Ecología 2009).

Threats to Survival. - Habitat loss represents the most serious threat to the persistence of T. coahuila and, if not halted in the near future, could lead to extinction of the species in the wild. Of all the aquatic habitats in Cuatro Ciénegas, the wetland habitats of T. coahuila are the most susceptible to drying due to their shallow nature, distance from source springs, and upstream diversions. For over a century, water diversions via man-made canals and pumped groundwater have extensively altered the hydrology of the Cuatro Ciénegas Basin, thereby lowering the water table (Fig. 8; Minckley 1969; Minckley 1992; Hendrickson et al. 2008; Wolaver et al. 2008). Canals in Cuatro Ciénegas serve agriculture, primarily crops such as alfalfa and pe- cans, both within and outside of the basin. The primary canal in the western portion of the basin, the La Becerra Canal (discharge rate mean \pm SD: $578 \pm 26 \mathrm{~L} / \mathrm{s}$; Wolaver et al.2008), irrigates agriculture (alfalfa) near the town of Cuatrociénegas de Carranza. The other main canals in the basin, the Santa Tecla Canal (discharge rate mean \pm SD: $187 \pm 29 \mathrm{~L} / \mathrm{s}$; Wolaver et al. 2008) and the Saca Salada Canal (discharge rate mean \pm SD: $1150 \pm 188 \mathrm{~L} / \mathrm{s}$; Wolaver et al. 2008), move water from the Cuatro Ciénegas Basin into the Rio Salada de los Nadadores to the east, where the water irrigates agriculture in the San Buenaventura valley. The older canals in Cuatro Ciénegas dating back to the late 1880 s, including the Saca Salada, were excavated simply (Fig. 8), while more modern canals such as Becerra and the new Santa Tecla are lined with concrete to prevent leakage and facilitate water flow (Fig. 8). Some older canals (e.g., Canal Don Julio) have been lined with plastic sheeting to prevent seepage. Lining of the canals and associated high flow rates prevent wetland plants such as cattail (Typha sp.) and sedge from establishing within the canals (Fig. 8) and therefore reduces the quality of potential corridors for movement of $T$. coahuila.

Currently, the National Water Commission of Mexico is replacing canals with pipelines in Cuatro Ciénegas. The conversion has started with the Santa Tecla Canal, and there are plans to continue with replacement of both the La Becerra and Saca Salada canals. To our knowledge, no agreements have been reached regarding the possibility that this increased efficiency of water diversion might be regulated to allow a portion of the water to remain in wetlands within Cuatro Ciénegas (Dean Hendrickson, pers. comm. 2010).

The consequences of continuous aquatic habitat loss in Cuatro Ciénegas were forewarned early by biologists. Webb et al. (1963) suggested, "Prolonged and intensive collecting, as well as deterioration of habitat through the construction of irrigation canals and agrarian development, could endanger the species because of the isolation of some habitats." Subsequently, William Garstka (pers. comm., 1978) documented wetland habitat loss in written correspondence to the Bronx Zoo by stating, "Since 1974... I've noticed a marked change in the aquatic habitat: the people are draining the swamps and collecting the spring's runoff in canals for irrigation and to channel to the steel mill at nearby Monclova. An area that was marsh in 1974 is now dust; another marsh is now an agricultural field." Smith and Smith (1979) also noted cause for concern by saying, "... only by careful choice can an area be designated that will be relatively immune from the eventual lowering of the water table that agricultural developments can be anticipated to bring." In the 47 years since these statements were published, insufficient progress has been made toward preserving habitats to ensure the persistence of $T$. coahuila and the other endemic aquatic species of Cuatro Ciénegas.

Numerous additional human-mediated threats jeopardize the survival of T. coahuila in Cuatro Ciénegas. First, the exotic Giant Reed (Arundo donax) and the native invasive 
Common Reed (Phragmites australis) alter the quantity and quality of wetland habitats occupied by $T$. coahuila. Both of these reed species reduce available wetland surface area due to their highly dense shoot biomass which causes a localized decrease in ground water (via an increase in water uptake; McGaugh et al. 2006). Second, stochastic variation in the drying of seasonal wetlands due to a drop in the water table, in addition to permanent changes in vegetation cover, may affect $T$. coahuila egg incubation temperatures and thus may lead to a skewed sex ratio in the species. Impacts of climate change on sex ratios are also a serious concern in future generations of $T$. coahuila. Third, high densities of horses throughout the basin, as observed at Antiguos Mineros in particular, cause degradation of wetland perimeters. Trampling by horses results in cracked and disfigured carapaces of the turtles. Fourth, direct turtle mortality from vehicle collision is also a concern. Dead $T$. coahuila have been documented on the two-lane highway running through the Área de Protección de Flora y Fauna Cuatro Ciénegas (Highway 40; construction started for four-lane expansion, Dean Hendrickson, pers.comm. 2010) as well as on the unpaved road which services all of the ejidos in the eastern portion of the valley. Finally, there is continuing illegal collecting and trade of $T$. coahuila by Cuatro Ciénegas residents and poachers.

Conservation Measures Taken. - In 1994, the Mexican government declared 84,347 ha of the Cuatro Ciénegas Basin as a national protected area, the Área de Protección de Flora y Fauna Cuatro Ciénegas (APFFCC; Secretaría Desarrollo Social 1994). The protected area staff is charged with monitoring tourists and habitats of Cuatro Ciénegas and regulating scientific research following the guidelines outlined in an official APFFCC management plan (Secretaría del Medio Ambiente y Recursos Naturales 1999). In 2007, the APFFCC was included in a new Área de Protección de Recursos Naturales which encompasses 1,519,920 ha. Although the APFFCC is a federal reserve, the three main irrigation canals in Cuatro Ciénegas originate and run through it; thus the sanctuary afforded for T. coahuila by the APFFCC is limited.

The Cuatro Ciénegas Basin has received international support to increase conservation practices and awareness. In 1995, the site was designated a Wetland of International Importance (Secretariat of the Ramsar Convention on Wetlands 2008). More recently, Cuatro Ciénegas was declared by the United Nations Educational, Scientific, and Cultural Organization (UNESCO) as a Man and the Biosphere Reserve (UNESCO-MAB 2006). Cuatro Ciénegas is also ranked as a high priority conservation site by the World Wildlife Fund (Abell et al. 2000, 2008) and The Nature Conservancy's Parks in Peril program. The APFFCC has received financial support from the World Bank's Global Environmental Facility to subsidize a number of internal programs, including field monitoring of the valley and environmental education.

Terrapene coahuila is listed as Endangered by the IUCN Red List (van Dijk et al. 2007), Endangered by the U.S.
Endangered Species Act (USFWS 1973), and a Species of Special Protection by the Mexican Government (Secretaría del Medio Ambiente y Recursos Naturales 2001).

Conservation Measures Proposed. - As we have documented above, $T$. coahuila is primarily threatened by wetland habitat loss. An integrative management plan implementing local regulation and monitoring of water extraction within the Cuatro Ciénegas Basin, and the regional aquifers that contribute water to Cuatro Ciénegas, is critical for the protection of the species. Restoring wetland habitats in the western portion of the basin, ranging from the Ejido San Marcos to Poza Anteojo, will be essential to maintaining genetic diversity in $T$. coahuila and other endemic aquatic species. Interestingly, when the major canal that serves the western lobe of the basin, the La Becerra Canal, was closed in 2007 , immediately (within 48 hours) the desiccated wetlands west of Poza de la Becerra refilled (Howeth, pers.obs., Hendrickson et al. 2008). This rapid and positive response suggests that wetland habitat restoration is still a possibility in many areas if water extraction were decreased or halted. The proposed level of water conservation and associated monitoring of aquatic habitats will require close collaboration between the APFFCC, the local agricultural community, ejiditarios of the Cuatro Ciénegas Basin, biologists, and hydrogeologists. An increased level of federal species protection for T. coahuila may greatly facilitate and provide impetus for formulating a water management plan.

In a turtle workshop held in conjunction with the 2007 Cuatro Ciénegas Researcher's Meeting, it was formally recommended to the APFFCC and SEMARNAT that the status of T. coahuila in Mexico be upgraded from a Species of Special Protection to Endangered. This proposition is in part based upon the species' ranked status derived from the federal guidelines outlined in NOM-059-ECOL-2001 (Secretaría del Medio Ambiente y Recursos Naturales 2001), and from criteria including: 1) the size of geographic distribution in Mexico, 2) habitat quality with reference to the species' requirements, 3) intrinsic biological vulnerability, and 4) impact of human activity on the species. Based upon this scale, a species score of 15 for T. coahuila places it above the 12-14 points required to be listed as Endangered in Mexico. To date, however, no action has been taken by SEMARNAT outside of the 2008 request for public commentary on revision of all Mexican species listed in NOM-059-ECOL-2001 (Secretaría del Medio Ambiente y Recursos Naturales 2008).

Other human-related threats to T. coahuila need to be improved in the near future. A reduction in road mortality caused by vehicle collisions can be achieved by rerouting both paved and unpaved roads where possible (e.g., one heavy-usage unpaved road runs through the center of $T$. coahuila habitat at Antiguos Mineros). Finally, prescribed burning should be employed in the valley to mimic presumed natural historic fire regimes and reduce the accumulation of unnaturally dense plant biomass that increases water demands and impedes turtle movement (e.g., Fig. 6). Controlled burns which are carelessly managed, however, can 
lead to unintentional mortality of $T$. coahuila (e.g., Max Nickerson, pers. comm. 1969; controlled burn at Pozas Azules 2006).

Several aspects of the ecology and behavior of $T$. coahuila in Cuatro Ciénegas remain unknown. There are multiple lines of ecological research that need to be addressed in order to better design an in situ conservation plan for the species. First, little is known about the breeding biology and nesting habits of $T$. coahuila. Understanding aspects of nesting ecology will likely elucidate factors affecting the apparently low levels of recruitment we have observed. Determining the location of nest sites and the potential for natal homing by females is a critical research need. Second, a recent mark-recapture study suggested that long-distance movement is an important adaptive response in the turtle's tracking of viable wetland habitats (Howeth et al. 2008). Identifying the routes that $T$. coahuila uses during its longdistance seasonal dispersal events will be vital to identifying migration corridors in need of special protection. Third, long-term mark-recapture studies of several populations would be useful to understand individual growth rates and population demography as they may relate to habitat loss and destruction.

Captive Husbandry. - Captive breeding programs have provided an invaluable source of information on growth, reproduction, and longevity in $T$. coahuila (e.g., Cerda and Waugh 1992). Small captive colonies of $T$. coahuila are located in a few zoos and private holdings throughout the United States and Europe, including the Gladys Porter Zoo (Brownsville, Texas, USA). Captives in these zoos originated from wild-caught adults (e.g., Dallas Zoo, Gladys Porter Zoo) or captive-bred stock (e.g., Jersey Wildlife Preservation Trust). Unfortunately, the number of zoos that breed and house $T$. coahuila has greatly declined over the last 20 years. Several of the main breeders of $T$. coahuila, including the Bronx Zoo (Bronx, New York, USA), the Dallas Zoo, and the Jersey Trust, disbanded their colonies and the captive individuals were disbursed widely.

Both public and private breeders of T. coahuila should actively maintain official studbooks in order to ensure its genetic viability, especially as the species approaches extinction in the wild in Cuatro Ciénegas. Studbooks document the origin and holdings of captive $T$. coahuila and, in conjunction with genotyping and the exchange of individuals, could guarantee a global source of outbred $T$. coahuila. The American Zoological Association (AZA) Studbook (Moorhead 2010) and the European studbook (Meijer and Zwartepoorte 2007) greatly aid efforts to document the status of $T$. coahuila in captivity. Currently, there are 55 adult (reproductively mature) females and 20 adult males in the AZA studbook (Moorhead 2010) and 21 adult females and 14 adult males in the European studbook (Hans Meijer, pers. comm. 2010). The management of captive T. coahuila colonies in the United States is directed by a Population Management Plan which involves voluntary cooperation of AZA-accredited zoos (Beth Moorhead, Houston Zoo, Texas, USA, pers. comm. 2010).
Current Research. - Along-term monitoring program for $T$. coahuila was formulated in 2007 by a collaborative effort between research biologists, non-governmental organizations (Pronatura Noreste, The Nature Conservancy), and APFFCC staff at a turtle workshop held in Cuatro Ciénegas. The monitoring plan emphasizes estimation of local population sizes from monthly mark-recapture data for several populations. This plan has not yet been enacted by either the APFFCC or academic biologists.

Acknowledgments. - We thank Dean Hendrickson and Jim Buskirk for comments and literature that improved earlier versions of the manuscript.R. Bruce Bury graciously provided his field notes recording the only known long-term recapture of a marked turtle from the original study of WSB. Dean Hendrickson, Adam Cohen, and Arturo Contreras-Arquieta are gratefully acknowledged for their resurvey efforts of the study wetlands of WSB in July 2002. WSB thanks his wife, Sheila Tuttle, and colleagues Alvin and Arianna Breisch, for accompanying him on the excursion to Cuatro Ciénegas in 2002, and for their field assistance during the wetland resurvey. Collaboration with John Legler (University of Utah) has been helpful in retrieving previous data on the species for his forthcoming monograph on Mexican turtles. WSB wishes to convey his respect, posthumously, to W.L. Minckley for his original introduction to Cuatro Ciénegas and for his guidance during the field study of T. coahuila.

\section{LITERATURE CITED}

Abell, R., Thieme, M.L., Revenga, C., Bryer, M., Kottelat, M., Bogutskaya, N., CoAd, B., MANDRAK, N., BaLderas, S.C., Bussing, W.,Stiassny,M.L.J.,Skelton,P.,AlLEn, G.R.,UnMaCk,P., NASEKA, A., Ng, R., Sindorf, N., Robertson, J., Armijo, E., Higgins, J. V., Heibel, T.J., Wikramanayake,E., Olson,D.,LoPez,H.L.,Reis, R.E., Lundberg, J.G., Perez, M.H. S., and Petry, P. 2008. Freshwater ecoregions of the world: A new map of biogeographic units for freshwater biodiversity conservation. Bioscience 58:403-414.

Abell, R.A., Olson, D.M., Dinerstein, E., Hurley, P.T., Digg, J.T., Eichbaum, W., Walters, S., Wettengel, W.,Allnutt, T., Loucks, C. J., AND HEDAO, P. 2000. Freshwater Ecoregions of North America: A Conservation Assessment. Washington, DC: Island Press.

AUFFENBERG,W.1958.Fossilturtles of the genus Terrapene inFlorida.Bulletin of the Florida State Museum, Biological Sciences 3:53-92.

BAUER, M. AND JASSER-HäGER, I. 2006. The Mexican aquatic box turtle, Terrapene coahuila Schmidt and Owens, 1944. Husbandry and breeding to the $\mathrm{F}_{2}$ generation. Radiata 15:40-49.

BRAMBLE, D.M. 1974. Emydid shell kinesis: biomechanics and evolution. Copeia 1974:707-727.

BRown, W.S. 1967. Natural history of Terrapene coahuila, a relict aquatic box turtle in northern Mexico. Master's Thesis, Arizona State University, Tempe.

BRown, W.S. 1971. Morphometrics of Terrapene coahuila (Chelonia, Emydidae), with comments on its evolutionary status. Southwestern Naturalist 16:171-184.

BRown,W.S.1974.Ecology of the aquatic box turtle,Terrapene coahuila (Chelonia, Emydidae) in Northern Mexico. Bulletin of the Florida State Museum, Biological Sciences 19:1-67.

Buhlmann, K.A., Akre, T.S.B., Iverson, J.B., Karapatakis, D., MitTERMEIER, R.A., GEORges, A., Rhodin, A.G.J., van DiJK, P.P., AND 
GiBBons, J.W. 2009. A global analysis of tortoise and freshwater turtle distributions with identification of priority conservation areas. Chelonian Conservation and Biology 8(2):116-149.

Burke, R.L., Leuteritz, T.E., AND Wolf, A.J.. 1996. Phylogenetic relationships of emydine turtles. Herpetologica 52:572-584.

CARSON, E.W. and DowLING, T.E. 2006. Influence of hydrogeographic history and hybridization on the distribution of genetic variation in the pupfishes Cyprinodon atrorus and C. bifasciatus. Molecular Ecology 15:667-679.

CERDA,A.ANDWAUGH,D. 1992.Statusand management of the Mexican box terrapin Terrapene coahuila at the Jersey Wildlife Preservation Trust. Dodo 28:126-142.

Feldman, C.R. And Parham, J.F. 2002. Molecular phylogenetics of emydine turtles:taxonomic revision and the evolution of shell kinesis. Molecular Phylogenetics and Evolution 22:388-398.

Hendrickson, D.A., Marks, J.C., Moline, A.B., Dinger, E.C., AND COHEN,A.E.2008.Combining ecological research and conservation: A case study in Cuatro Ciénegas, Coahuila, Mexico, In: Stevens, L. and Meretsky, V.J. (Eds.). Aridland Springs in North America: Ecology and Conservation. University of Arizona Press, Tucson, Arizona, pp. 127-157.

Howeth,J.G.,McGaugh,S.E., ANDHendrickson,D.A. 2008.Contrasting demographic and genetic estimates of dispersal in the endangered Coahuilan box turtle: a contemporary approach to conservation. Molecular Ecology 17:4209-4221.

Instituto Nacional de Ecología. 2009. Sistematización de datos de los piezómetros de los cuerpos de agua en Cuatro Ciénegas. http:// www.ine.gob.mx/emc-cuatrocienegas/471-emc-cuatrocienegasmediciones downloaded 21 February 2010.

IVERSON, J.B. 1982. Biomass in turtle populations: a neglected subject. Oecologia 55:69-76.

Iverson, J.B. 1992. A Revised Checklist with Distribution Maps of the Turtles of the World. Richmond, IN: Privately published, $363 \mathrm{pp}$

Iverson, J.B., Brown, R M., AKre, T. S., NeAR, T.J.,Le, M., Thomson, R. C., Starkey, D. E. 2007. In search of the tree of life for turtles. Chelonian Research Monographs 4:85-106.

JoHNSON, S.G. 2005. Age, phylogeography and population structure of the microendemic banded spring snail, Mexipyrgus churinceanus. Molecular Ecology 14:2299-2311.

LEGLER, J.M. 1960. Natural history of the ornate box turtle, Terrapene ornata ornata Agassiz. University of Kansas. Publication of the Museum of Natural History 11:527-669.

McGaugh, S.E., Hendrickson, D.A., Bell, G., Cabral, H., Lyons, K., McEACHRON, L., AND MunOz, O. 2006. Fighting an aggressive wetlands invader:Acase study of giantreed (Arundo donax) and its threat toCuatroCiénegas,Coahuila,Mexico.In:M.d.1.Lozano-Vilanoand A. J. Contreras-Balderas (Eds.). Studies of North American Desert Fishes in Honor of E.P. (Phil) Pister, Conservationist. Universidad Autonoma de Nuevo Leon, Monterrey, Mexico, pp. 151-161.

MeiJer, H. AND ZwartePOORTE, H. 2007. Studbook breeding program: Terrapene coahuila, Coahuilan Box Turtle. European Studbook Foundation.

MERTENS,R.ANDWERMUTH,H.1955.DierezentenSchildkroten,Krokodile, und Bruckenechsen. Zoologische Jahrbucher 83:323-440.

MILLER, J.K. 2001. Escaping senescence: demographic data from the three-toed box turtle (Terrapene carolina triunguis). Experimental Gerontology 36:829-232.

MilsteAd, W.M. 1960. Relict species of the Chihuahuan Desert. Southwestern Naturalist 5:75-88.

MilsteAd, W.M. 1967. Fossil box turtles (Terrapene) from central North America and box turtles of eastern Mexico. Copeia 1967:168-179.
MilsteAd,W.M.And TinKLE,D.W.1967.Terrapene of Western Mexico, with comments on the species groups in the genus. Southwestern Naturalist 1:180-187.

MinCKLEY, W.L. 1966. Coyote predation on aquatic turtles. Journal of Mammalogy 47:137.

MinCKLEY,W.L. 1969. Environments of the bolson of Cuatro Ciénegas, Coahuila, Mexico with special reference to the aquatic biota. University of Texas, El Paso, Texas Science Series 2:1-63.

MinCKLEY, W.L. 1992. Three decades near Cuatro Ciénegas, Mexico: photographic documentationand apleaforarea conservation.Journal of the Arizona-Nevada Academy of Science 26:89-118.

MinCKLEy, W.L. AND Cole, G.A. 1968. Preliminary limnologic information on waters of the Cuatro Ciénegas Basin, Coahuila, Mexico. Southwestern Naturalist 13:421-431.

MinX,P. 1996.Phylogenetic relationships among the box turtles, Genus Terrapene. Herpetologica 52:584-597.

MoorheAD, B. 2010. AZA Regional Studbook: Aquatic Box Turtle (Terrapene coahuila). American Zoological Association.

MuRPHY,J.B. AND MitCHELL,L.A. 1984. Breeding the aquatic box turtle: Terrapene coahuila. International Zoo Yearbook 23:135-137

PINKAVA,D.J.1984.Vegetationand flora of the bolson ofCuatroCiénegas, Coahuila,Mexico: IV. Summary, endemism and corrected catalogue. Journal of the Arizona-Nevada Academy of Science 19:23-47.

SCHMIDT, K.P. AND OwENs, D.W. 1944. Amphibians and reptiles of northern Coahuila, Mexico. Field Museum of Natural History Zoological Series 29:97-115.

Secretaríadel MedioAmbiente y Recursos Naturales. 1999.Programa de manejo del área de protección de flora y fauna Cuatrociénegas, México. Instituto Nacional de Ecología, Tlacopac, Mexico.

Secretaríadel MedioAmbienteyRecursos Naturales.2001.NORMA Oficial Mexicana NOM-059-ECOL-2001, Protección ambientalEspecies nativas de México de flora y fauna silvestres-Categorías de riesgoy especificacionespara suinclusión,exclusión,ocambio-Lista de especies en riesgo. http://www.semarnat.gob.mx/leyesynormas/ Normas\%20Oficiales\%20Mexicanas\%20vigentes/NOM-ECOL059-2001.pdf downloaded 26 April 2010.

SeCretaría del MedioAmbiente y Recursos Naturales.2008.Proyecto demodificación alaNorma OficialdeMexicanaNOM-059-SEMARNAT-2001. Protección ambiental- Especies nativas de México de flora y fauna silvestres- Categorías de riesgo y especificaciones para su inclusión, exclusión, o cambio- Lista de especies en riesgo. http:// ss1.webkreator.com.mx/4_2/000/000/017/3ad/modifNOM059.pdf downloaded 26 April 2010.

Secretaría Desarrollo Social. 1994. Decreto por el que se declara como área protegida, con el carácter de protección de flora y fauna, la región conocida como Cuatrociénegas, municipio de Cuatro Ciénegas, Coahuila. Diario Oficial de la Federacion, Mexico CDXCIV:5-11.

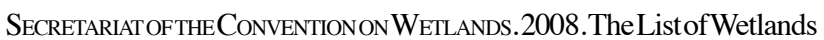
of International Importance. Ramsar, Gland, Switzerland.

Sмith, H.M. AND Smith, R.B. 1979. Synopsis of the Herpetofauna of Mexico. Volume VI. Guide to Mexican Turtles. Bibliographic Addendum III. John Johnson, North Bennington, Vermont.

StePHENS, P.R. and WIENS, J.J. 2003. Ecological diversification and phylogeny of emydid turtles. Biological Journal of the Linnean Society 79:577-610.

STEPHENS, P.R. and WIENS, J.J. 2008. Testing for evolutionary trade-offs in a phylogenetic context: ecological diversification and evolution of locomotor performance in emydid turtles. Journal of Evolutionary Biology 21:77-87.

STICKEL, L.E. AND BunCK, C.M. 1989. Growth and morphometrics of the box turtle, Terrapene c. carolina. Journal of Herpetology 23:216-223. 
UNESCO-MAB.2006. World network of biospherereserves.UNESCO, Paris, France.

USFWS. 1973. Title 50 -Wildlife and Fisheries; Chapter 1-Bureau of Sport Fisheries and Wildlife, Fish and Wildlife Service, Department of the Interior; Part 17 - Conservation of Endangered Species and Other Fish or Wildlife, Amendments to Lists of Endangered Fish and Wildlife. Federal Register 38:14678.

van DiJK, P.P., FloRes-VILlela, O., and Howeth, J. 2007. Terrapene coahuila.2007 IUCN Red List of Threatened Species. IUCN, www. iucnredlist.org downloaded 15 March 2008.

WeBb, R.G., MinCKLEY, W. L., AND CRADDOCK, J. E. 1963. Remarks on theCoahuilanBoxturtle,Terrapene coahuila(Testudines,Emydidae). Southwestern Naturalist 8:89-99.

Wiens, J.J., Kuczynski, C.A., And StePhens, P.R. 2010. Discordant mitochondrial and nuclear gene phylogenies in emydid turtles: implications for speciation and conservation. Biological Journal of the Linnean Society 99:455-461.

Williams, K.L., AND Han, P. 1964. A comparison of the density of Terrapene coahuila and T. carolina. Journal of the Ohio Herpetological
Society 4:105.

Williams, K.L., Smith, H.M., and Chrapliwy, P.S. 1960. Turtles and lizards from northern Mexico. Transactions of the Illinois Academy of Science 53:36-45.

WolaVer, B.D., Sharp, J.M.,RodrigUEZ, J.M., AND IBARRA Flores, J.C. 2008. Delineation of regional arid karstic aquifers: an integrative data approach. Ground Water 46:396-413.

\section{Citation Format for this Account:}

Howeth, J.G. AND BROwn, W.S. 2011. Terrapene coahuila Schmidt and Owens 1944 - Coahuilan Box Turtle. In: Rhodin, A.G.J., Pritchard, P.C.H., van Dijk, P.P., Saumure, R.A., Buhlmann, K.A., Iverson, J.B., and Mittermeier, R.A. (Eds.). Conservation Biology of Freshwater Turtles and Tortoises: A Compilation Project of the IUCN/SSC Tortoise and Freshwater Turtle Specialist Group. Chelonian Research Monographs No. 5, pp. 049.1-049.13, doi:10.3854/crm.5.049.coahuila.v1.2011, http:// www.iucn-tftsg.org/cbftt/. 